\title{
Ymmärtävätkö venäläiset ja ukrainalaiset toisiaan?
}

Työssäni venäjän kielen professorina työn yksi kiehtovimmista puolista ovat ne kysymykset, joita kansan syvät rivit minulle silloin tällöin sähköpostitse tai puhelimitse esittävät. Kysymys, johon olen yrittänyt vastata toistuvasti, koskee sitä, ymmärtävätkö venäläiset ja ukrainalaiset toisiaan. Menemättä kansallisidentiteetin ja kieli-identiteetin syövereihin sen tarkemmin oletan, että tällä tarkoitetaan, ovatko venäjän ja ukrainan kielet keskenään ymmärrettäviä. Viime vuosien tapahtumien samoin kuin jo pidemmänkin historian kulun pohjalta kun lienee selvää, että valtioina Venäjä ja Ukraina eivät useinkaan ymmärrä kovin hyvin toisiaan.

Kielitieteellisesti Ukrainan kielitilanteeseen liittyy useita kiinnostavia kysymyksiä. Ensimmäinen niistä liittyy kielten rajojen määrittelyyn. Mikä on venäjää ja mikä ukrainaa, voiko ne absoluuttisesti erottaa toisistaan? Ukrainan ja venäjän kielet ovat lähisukukieliä, jotka eroavat toisistaan etenkin äänteiden ja sanaston osalta, jossain määrin myös kieliopiltaan. Standardivenäjä ja standardiukraina ovat siten toki selvästi toisistaan erotettavissa. Kieltä käytettäessä on kuitenkin aina olemassa myös lukuisia muita variantteja, joita samakin puhuja käyttää eri tilanteissa ja eri ihmisten kanssa kommunikoidessaan. Ukrainan ja venäjän erottaminen toisistaan on vaikeaa myös siksi, että kieliä puhutaan Ukrainassa iloisesti sekaisin ja erittäin suuri osuus väestöstä hallitsee molemmat kielet ainakin jollain tasolla. Slaavialueilla ja muuallakin on erittäin tavallista, että etenkin rajaseuduilla sukukielten välillä on pikemminkin murteiden jatkumo kuin selkeä kielten raja.

Monikielisille tilanteille on maailmanlaajuisesti tyypillistä se, että kieltä vaihdetaan etenkin epäformaaleissa tilanteissa lennosta. Kielikontaktien tutkimus tuntee monenlaisia kahden tai useamman kielen yhdessä käyttämisen muotoja. Näitä ovat mm. kielten sekoittaminen, lainaaminen ja koodinvaihto eli usean kielen käyttö samassa kommunikaatiotilanteessa tai jopa samassa lauseessa. Ukrainassa eritasoista ukrainan ja venäjän sekakäyttöä ja niiden välistä koodinvaihtoa on kutsuttu nimellä suržik. Tämäkin on omanlaisensa kieli-ideologinen valinta - kontaktikielen nimeäminen kielimuodoksi antaa sille statuksen ja voi tehdä sen käytöstä identiteettikysymyksen.

Ukrainassa tammikuussa 2021 voimaan tulleen kielilain uudistuksen mukaan palvelualalla kuten ravintoloissa on käytettävä ukrainan kieltä. Palveluntarjoajan on siis tarjottava palvelua ukrainaksi. Venäjää voi käyttää vain asiakkaan aloitteesta, ja lain noudattamatta jättämisestä voi saada sakkoa. Olisi kielitieteellisesti kiehtovaa saada tietää, miten lakia tulkitaan. Mihin 
voidaan vetää raja näiden kahden kielen välillä? Riittävätkö ukrainankieliset tervehdykset tai esimerkiksi ukrainan sanojen käyttö täyttämään lain kirjaimen? Kuka jaksaa toimia kielipoliisina?

Ukraina on Ukrainan valtion ainoa virallinen kieli, (alaluokkia lukuun ottamatta) koulutuksen kieli ja virallisen dokumentaation kieli. Kielipoliittisesti Ukraina on täten valinnut yksikielisen kansalliseen identiteettiin perustuvan tien. Venäjän federaation yritykset pönkittää venäjän asemaa Ukrainassa nähdään osana pitkää valloittajan valta-aseman ketjua. Myös muiden Ukrainassa puhuttavien kielten kuten puolan ja unkarin asema on puhututtanut etenkin maan rajojen ulkopuolella.

Jos kielen voisi erottaa politiikasta, olisi mielestäni itsestään selvää, että ukrainalaisten luonteva kaksikielisyys on suuri rikkaus, jota on syytä kaikin keinoin vaalia. Kielivähemmistöjen oikeuksiin, koulutuksen kieleen ja kielisääntelyyn voi suhtautua sekä ideologisena että pragmaattisena kysymyksenä. Kielivalintojen ohjailussa käytetään kuitenkin väistämättä valtaa tavalla, joka pureutuu ihmisyyden ytimeen.

Ymmärtävätkö venäläiset ja ukrainalaiset siis toisiaan? Ukrainassa hyvin pitkälti ymmärtävät, ainakin kielen puolesta. Monissa tilanteissa kukin voi puhua kumpaa tahansa ilman, että käännöksille tulee tarvetta. Laajemmin kysymys on vaikeampi. Ukrainan kielen kanssa vähän tekemisissä ollut venäjänkielinen ei sitä välttämättä äkkiseltään ymmärrä, eikä esimerkiksi ukrainankielisten siirtolaisyhteisöjen jälkeläisille venäjäntaito ole ollenkaan itsestäänselvyys.

Ukrainalaisten kieliasenteita tutkittaessa tulokset ovat näennäisen ristiriitaisia. Kieliidentiteetillä ja kansallisella identiteetillä ja niihin liittyvillä asenteilla ei välttämättä ole suoraa suhdetta kielitaitoon. Laajemmat poliittiset asenteet ja sympatiat vaikuttavat myös kokemukseen ukrainan ja venäjän kielistä, niiden käytöstä ja kielipolitiikan toivotusta suunnasta.

Kielet, niiden oppiminen, käyttö eri tilanteissa ja tähän liittyvä vallankäyttö ovat aina paljon monimutkaisempia kysymyksiä kuin julkisesta keskustelusta voisi olettaa. Viime kädessä ihmiset käyttävät kieltä ja kieliä niin kuin itse haluavat ja lapset oppivat ne kielimuodot, joita heille puhutaan. Kun valinnanvaraa on, puhuttava kieli voidaan myös tietoisesti valita. Tällaisten valintojen seurauksina vähän puhuttuja kieliä on maailmassa kuollut muutamassa sukupolvessa. Kieli-identiteetteihin liittyvät tekijät ovat kuitenkin paljon vaikeammin säädeltävissä ja järjellä ymmärrettävissä kuin lakien säätäjät vaikuttavat tietävän. Samanaikaisesti kielikysymykset eivät kiinnosta läheskään kaikkia. Kielipolitiikassa äänekkäin on se usein hyvinkin pieni joukko, joka on siitä varsin voimallisesti jotain mieltä.

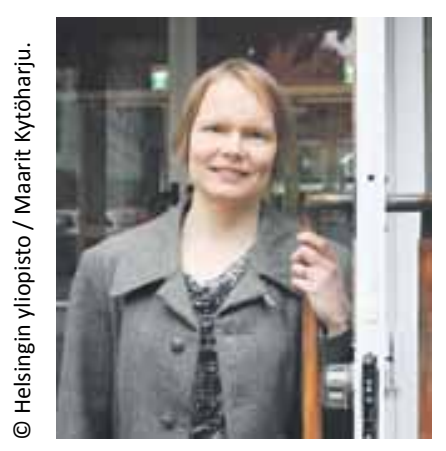

Johanna Viimaranta

Kirjoittaja on Helsingin yliopiston venäjän kielen professori. 